\title{
The effect of the cutting edge helix angle of the cutter on the process of chips removing from the cutting zone
}

\author{
Wpływ kąta pochylenia krawędzi skrawającej frezu na proces \\ odprowadzania wiórów ze strefy skrawania
}

\author{
JAN BUREK \\ ŁUKASZ ŻYŁKA \\ MARCIN PŁODZIEŃ \\ PAWEŁ SUŁKOWICZ \\ JAROSŁAW BUK*
}

The influence of the cutting edge helix angle of the end milling cutter on the chips removal process (angle and velocity) from the cutting zone during high-performance milling of $\mathrm{AIZn5.5MgCu}$ aluminum alloy is presented.

KEYWORDS: end mill, helix angle, aluminum, high performance cutting

Aluminum alloys with their unique properties such as low density, low specific cutting force and good machinability (in particular by machining), are used in aviation, aerospace and automotive industries. In the aviation industry, the most commonly used aluminum alloy is the AIZn5.5MgCu wrought alloy. It can be found in the construction of load-bearing elements of aircrafts, e.g. frames, stringers, spars and fuselage as well as wings $[1-3,5]$.

Integral, homogeneous structural components are manufactured from a complete block of material by milling. Many times during machining of this type of elements, more than $90 \%$ of the material is removed in the form of chips. A characteristic feature of the complex structure are thin walls and large number of closed areas with relatively large depth [4-7].

Due to the thin-walled structure of the aluminum alloy integral structures and large volume of material removed, the material removal machining of these components is carried out in a multi-stage manner. The first step roughing and shaping - is performed by high performance cutting (HPC) method, which consists of removing the material in the shortest possible time by increasing the volume of removed material $Q_{w}$, i.e. radial infeed $a_{e}$, axial infeed $a_{p}$ and feedrate per tooth $f_{z}$ (fig. 1 ). The HPC machining, apart from undeniable advantages, has some limitations, including those related with the removal of a significant amount of chips from the cutting zone, which may cause filling up a flute. These problems increase when machining closed areas with relatively large depths (pockets) (fig. 2) [5, 9].

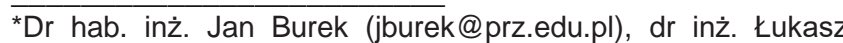
Żyłka (zylka@prz.edu.pl), dr inż. Marcin Płodzień (plodzien@prz.edu.pl), mgr inż. Paweł Sułkowicz (psulkowicz@prz.edu.pl), mgr inż. Jarosław Buk (jbuk@prz.edu.pl) - Katedra Technik Wytwarzania i Automatyzacji na Politechnice Rzeszowskiej
}

DOI: https://doi.org/10.17814/mechanik.2017.11.152

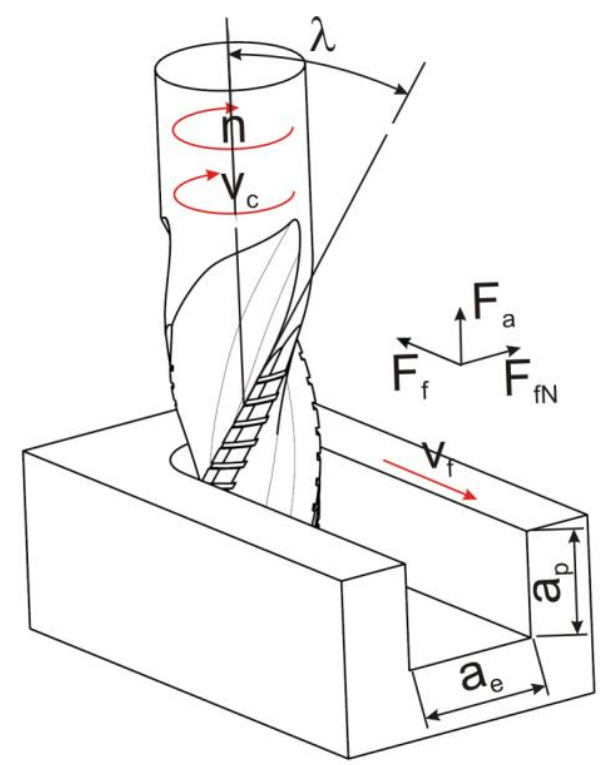

Fig. 1. HPC milling process parameters: $a_{p}$ - axial infeed, $a_{e}$ radial infeed, $v_{f}$ - feedrate, $n$ - rotational speed of cutter, $v_{c}$ cutting speed, $\lambda$ - cutting edge inclination

Our own experiments revealed that the chip removal process can be significantly accelerated by the appropriate selection of the shape and the helix angle of the cutting edge $[4,5,11]$. It has been shown that the use of a wavy or interrupted cutting edge shape contributes to a $30 \%$ reduction in cutting force $F_{f N}$ as compared to a continuous shape of the cutting edge. Reduction of chips dimensions and significant fragmentation were also obtained, regardless of the axial infeed $a_{p}[1,2,4,5,10]$.

\section{Inclination of the cutting edge}

Together with the cutting edge of the end mill, the mill flutes are also inclined, which is of great importance in the removal of chips from the cutting zone. The helix angle of the cutting edge $\lambda$ has a significant influence on the conditions of chip removal from the cutting zone, since its value determines the distribution of the chip velocity vectors in the flute (fig. 2). Depending on the angle $\lambda$, the velocity of chip removal changes as well. Moreover, the helix angle of the cutting edge substantially affects the direction of the chip removal, which at low angles is axial, and at high ones - changes into radial. Changing the angle $\lambda$ also contributes to the 
change in the cutting force components (feed force $F_{f}$, flapper force $F_{f N}$ and axial force $\left.F_{a}\right)[3,9,11]$.
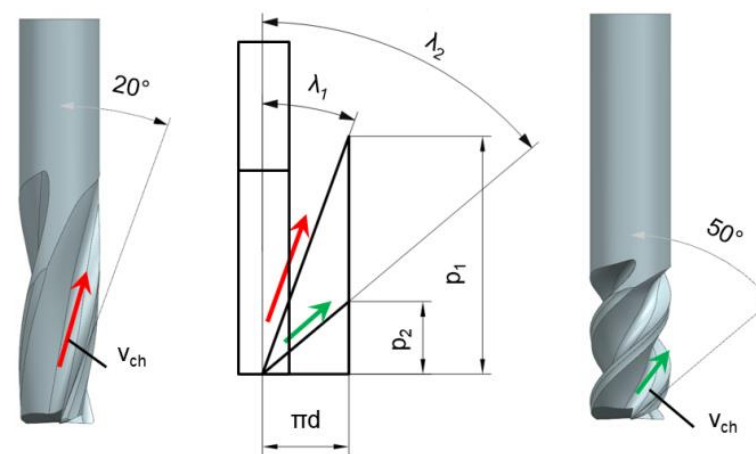

$$
\begin{array}{ll}
\text { Low helix angle of the cutting edge } \lambda: & \text { High helix angle of the chip } \lambda \text { : } \\
\text { - Velocity of the chip } \mathbf{v}_{\mathrm{ch}} \uparrow & \text { - Velocity of the chip } \mathbf{v}_{\mathrm{ch}} \downarrow \\
\text { - Cutting force component } \mathrm{F}_{\mathrm{f}} \mathrm{F}_{\mathrm{fN}} \downarrow & \text { - Cutting force component } \mathrm{F}_{\mathrm{f}}, \mathrm{F}_{\mathrm{fN}} \uparrow
\end{array}
$$

Fig. 2. Effect of cutting edge inclination angle on chip removal and cutting forces components

In this paper, we present results of investigations of the influence of the cutting edge helix angle on the speed and angle of chip removal from the cutting zone.

\section{Test conditions}

Testing of the chip removal process was performed on DMG - 80 DuoBlock multi-axis machining center (fig. 3).

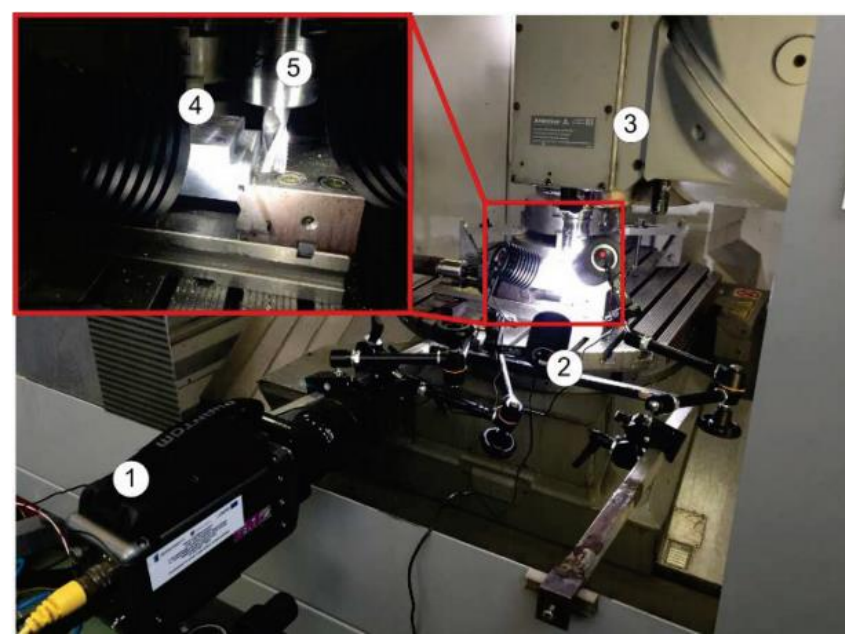

Fig. 3. Test station for rapid variable processes measurement: 1 - high-speed camera, 2 - LED lighting system, 3 - 5-axial milling center 80 DuoBlock, 4 - test specimen, 5 - tested cutter

Measurements of the chip removal process (angle and velocity) were performed using the Vision Research Phantome V.9.1 camera. The camera recorded $480 \times 480$ pixels with a maximum frame rate of $k l_{\max }=6400 \mathrm{fps}$.

Three tooth end mill solid carbide cutters with a diameter of $d=20 \mathrm{~mm}$ and a helix angle $\lambda$ of the cutting edge varying from $20^{\circ}$ to $50^{\circ}$ at $5^{\circ}$ steps (fig. 4a). Milling cutters had alternating wavy-variable cutting edge (fig. $4 \mathrm{~b})$. The $100 \times 100 \times 50 \mathrm{~mm}$ rectangular samples were made of AIZn5.5MgCu aluminum alloy.

Milling tests for all cutting tools were performed with constant technological parameters (Table). In order to record a smooth image of the cutting tooths and the process of chips removal in the light beam of the luminaires, the maximum possible cutting speed $v_{c}$ was determined from the equation:

$$
v_{\mathrm{c}}=\frac{\Pi d}{1000} \cdot \frac{k l_{\max } \cdot 60}{z \cdot k l_{\mathrm{z}}}, \mathrm{m} / \mathrm{min}
$$

where: $d$ - tool diameter, $k l_{\max }$ - maximum number of frames recorded by the camera, $z$ - number of cutting tooths, $k l_{z}=25 \mathrm{fps}$ - number of frames per a single cutting edge.

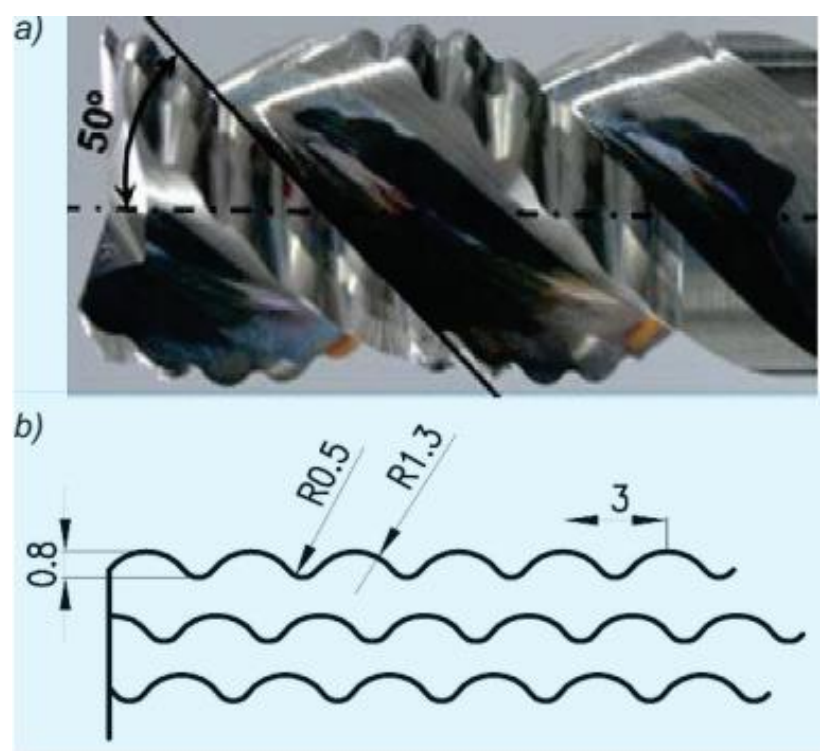

Fig. 4. Solid carbide cutter: a) cutter with helix angle $\lambda=50^{\circ}$, b) geometry of the wavy cutting edge

\section{TABLE. Technological parameters}

\begin{tabular}{|l|c|}
\hline Cutting speed $v_{\mathrm{c}}, \mathrm{m} / \mathrm{min}$ & 321 \\
\hline Axial infeed $\mathrm{a}_{\mathrm{p}}, \mathrm{mm}$ & 15 \\
\hline Radial infeed $\mathrm{a}_{\mathrm{e}}, \mathrm{mm}$ & 8 \\
\hline Feedrate on the blade $\mathrm{f}_{\mathrm{z}}, \mathrm{mm} / \mathrm{blade}$ & 0,075 \\
\hline
\end{tabular}

\section{Experimental results}

Sample recorded images showing the influence of the cutting edge helix angle on the chip removal process for angles $\lambda=20^{\circ}$ and $\lambda=50^{\circ}$ are shown in fig. 5 and fig. 6 .
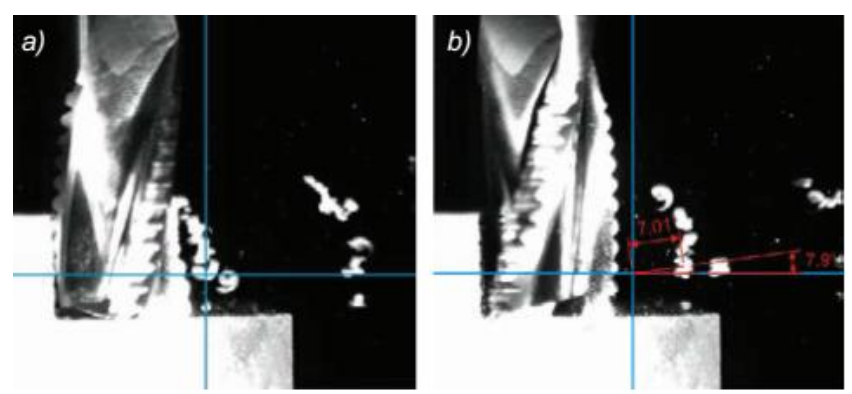

Fig. 5. Chip removal process for angle of inclination of cutting edge $\lambda=20^{\circ}$ : a) chip in position 0 of image frame, b) chip after 10 frames of image 

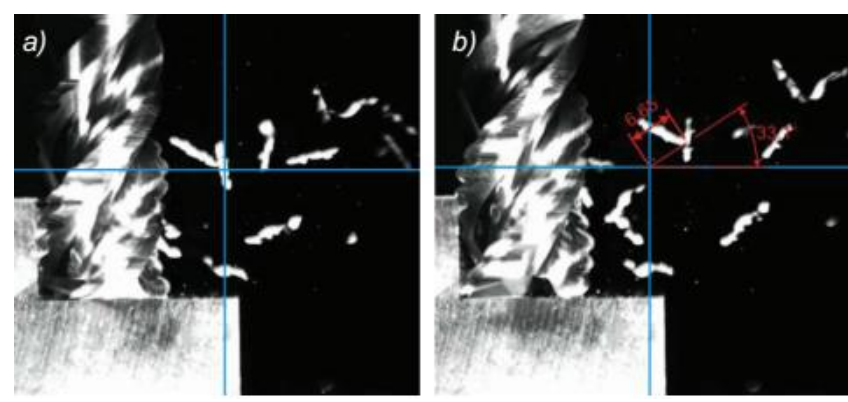

Figure 6. Chip removal process for angle of inclination of cutting edge $\lambda=50^{\circ}$ : a) chip in position 0 of image frames, b) chip after 10 frames of image

The results show a significant influence of the helix angle of the cutting edge on the process of chip evacuation from the cutting zone and the process of chip formation and their form. Increasing the helix angle of the cutting edge results in a change in the shape from the spiral-conical shape in the case of angle $\lambda=20^{\circ}$ (fig. 5b) to the open helical form in the case of angle $\lambda=50^{\circ}$ (fig. $6 b)$.

The evacuation angle and chip velocity analysis was carried out on the basis of displacement of randomly selected 5 chips and then the mean values from the measurements obtained were determined. Fig. 7 and fig. 8 illustrate the influence of helix angle of the cutting edge $\lambda$ on the evacuation angle $\delta_{c h}$ and the speed of the chip $v_{c h}$.

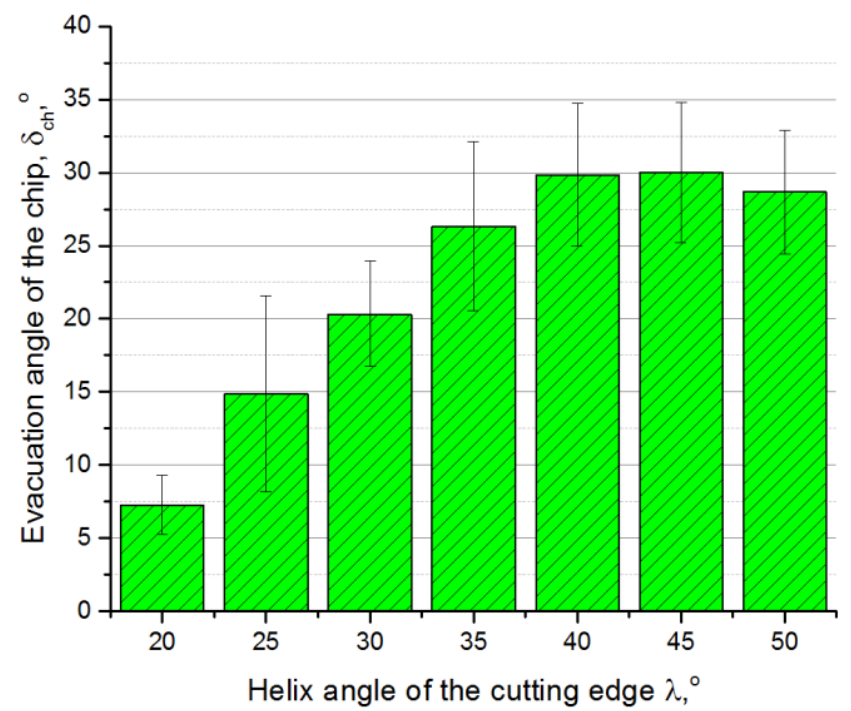

Fig. 7. Influence of the helix angle of the cutting edge $\lambda$ on the evacuation angle of the chip $\delta_{c h}$

In the range of the cutting edge helix angle $\lambda=20-40^{\circ}$, a linear increase in the chip angle $\delta_{c h}$ was observed in the range of $7 \div 30^{\circ}$. Further increase of the cutting edge angle $\lambda$ no longer results in a significant increase in the chip evacuation angle $\delta_{c h}$, the mean value of which for the helix angle $\lambda=30 \div 50^{\circ}$ was about $28^{\circ}$.

The highest speed of chip movement was obtained in the range $\lambda=30 \div 40^{\circ}$. The average value of this range was $350 \mathrm{~m} / \mathrm{min}$ and was $10 \%$ higher than the cutting speed $v_{c}$. Applying tilts of $\lambda$ less than $30^{\circ}$ and larger than $40^{\circ}$ will reduce the chip speed. The lowest $v_{c h}$ speed was obtained for the helix angle $\lambda=50^{\circ}$ and it was about 270 $\mathrm{m} / \mathrm{min}$.

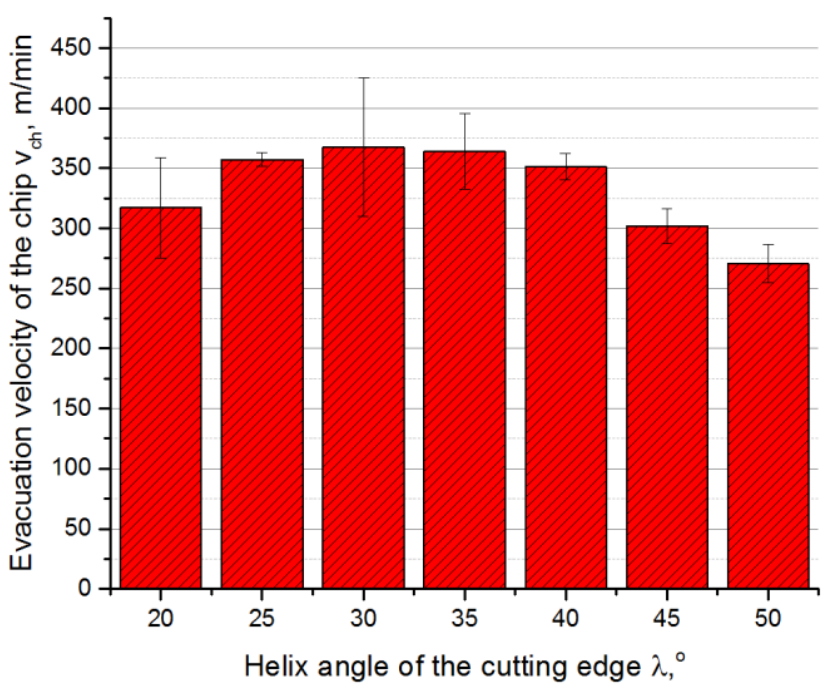

Fig. 8. Effect of helix angle of the cutting edge $\lambda$ on evacuation velocity of the chip $v_{c h}$

In addition, large dispersion of the chip evacuation angle $\delta_{c h}$ and chip velocity $v_{c h}$ was observed. Such large changes occurred because of the emerging rotations of chips in the cutting zone, interaction between chips, resulting in a change in the angle of evacuation and the velocity of chips, as well as the impact of chips on the workpiece, changes in the form of chips and the variation of frictional forces during chip formation.

\section{Conclusions}

The results show that the change in the helix angle $\lambda$ of the cutting edge contributes to the process of chip evacuation from the cutting zone (angle $\delta_{c h}$ and removal velocity $v_{c h}$ ).

In the case of the cutting edge helix angle of $30^{\circ}<\lambda<40^{\circ}$, the test showed higher chip evacuation rates $v_{c h}$ from the cutting zone. In turn, the use of cutting edge angles $\lambda>40^{\circ}$ decreases the speed of chip evacuation $v_{c h}$ below the cutting speed $v_{c}$. Applying the $\lambda>40^{\circ}$ cutting edge angles results in the highest $\delta_{c h}$ chip evacuation angles from the cutting zone - approximately $30^{\circ}$. For angles $\lambda<40^{\circ}$, a linear reduction of the chip evacuation angle $\delta_{c h}$ from $25^{\circ}$ to $6^{\circ}$ is observed.

Value of the helix angle also influences on the shape and size of chips. In the case of the cutting edge helix angle $\lambda<40^{\circ}$, the chips were smaller and more fragmented. In contrast, the use of a cutting helix angle $\lambda>40^{\circ}$ results in chips of much larger dimensions and less fragmentation.

Summing up the results of the $\delta_{c h}$ evacuation angle and $v_{c h}$ chip velocity in the case of a wavy milling cutter, it was found that it is preferable to use a cutting edge helix angle of $\lambda=35 \div 40^{\circ}$.

\section{REFERENCES}

1. Burek J., Żyłka Ł., Płodzień M., Buk J. „Wpływ zarysu ostrza freza na kształtowanie wiórów w wysokowydajnym frezowaniu stopu aluminium". Mechanik. 8-9 (2016).

2. Burek J., Żyłka Ł., Płodzień M., Gdula M. „Wpływ zarysu linii ostrza freza na siłę skrawania w procesie wysokowydajnej obróbki stopu AIZn5.5MgCu". Mechanik. 8-9 (2015).

3. Kuczmaszewski J., Zaleski K. „Obróbka skrawaniem stopów aluminium i magnezu”. Lublin: OWPL, 2015. 
4. Burek J. Płodzień M. „Wysoko wydajna obróbka części ze stopów aluminium o złożonych kształtach". Mechanik. 7 (2012): pp. 542-549.

5. Kawalec A., Oczoś K.E. „Kształtowanie metali lekkich”. Warszawa: PWN, 2012.

6. Campbell F.C. „Manufacturing Technology for Aerospace Structural Materials". Elsevier, 2006.

7. Oczoś K.E. „Doskonalenie procesów kształtowania ubytkowego stopów aluminium”. Mechanik. 3 (2009), pp. 153-163, 4 (2009), pp. 249-256.

8. Demir H., Gündüz S. "The effects of aging on machinability of 6061 aluminium alloy". J Mater Des. 30, 5 (2009): pp.: 1480-1483.

9. Groppe M. „Prozessauslengung für die Hochleistungfräsbearbeitung von AluminiumStrukturbauteilen“. Dr.-Ing. Dissertation. Hannover, 2005

10. Zhang L., Zheng L. „Prediction of cutting forces in end milling of pockets". Int Journal Adv Manu Technol. 25 (2005): pp. 281-287.

11. Trent E.M., Wright P.K. "Metal Cutting". 4th edn. Butterworth-Heinemann, USA, 2000, pp. 439. 